\title{
An Examination of Undergraduate Student Participation Within an Interdisciplinary Business Course
}

\author{
Ellen M. Raineri \\ Penn State University
}

Criticisms of business courses include a lack of relevancy and theoretical application. Using interdisciplinary business courses resolve such issues. Accordingly, an undergraduate business course on Corporate Social Responsibility (CSR) combined marketing activities within a service learning project. Student participation within three deliverables is discussed. The first, a CSR Marketing Analysis Report to guide students in evaluating an organization's marketing initiatives. The second, a CSR Marketing Action Plan to identify marketing initiatives for completion. The third, a Final Presentation and a Reflection Paper. Additionally, this paper summarizes the completed marketing projects and synthesizes benefits experienced by students and their selected organizations.

Keywords: Corporate Social Responsibility (CSR), service learning, interdisciplinary, marketing, undergraduate business course

\section{INTRODUCTION}

Business courses have been criticized for having too much theory while not having enough application, relevancy, and practical value for employers (Behrman \& Levin, 1984; Bennis, \& O’Toole, 2005; Edelson, Senk, \& Stock, 2018; Stewart, 1984). Fortunately, numerous pedagogical solutions have resolved these challenges. For example, Navarro (2008) highlights the importance of having interdisciplinary courses as well as experiential learning to supplement the commonly used "chalkboard teaching."

Others also advocate the solution of integration within courses (Bennis, \& O'Toole, 2005; Cummings, 2007; Grey, 1996; McCord, Houseworth, \& Michaelsen, 2015). The use of interdisciplinary courses as well as action-based learning contribute to optimal integration (McCord, Houseworth, \& Michaelsen, 2015; Reynolds \& Vince, 2004).

Another remedy focuses on the use of academic service learning because it fosters experiential or action learning by applying academic theory to real world situations (Chuang \& Chen, 2013). In addition to students engaging in action learning, they also engage in reflection. A result is that reciprocity occurs between the students engaging in service learning and the organizations that are the recipients (Bailey, Carpenter, \& Harrington, 2002; Nokes, Nickitas, Keida \& Neville, 2005). For students, benefits include increased engagement (Lillo, 2019; Thomas \& Smith, 2017), improved critical thinking (Campbell \& Oswald, 2018; Celio, Durlak, \& Dymnicki, 2011; Sedlak, Doheny, Panthofer, \& Anaya, 2003) and improved problem solving (Guo et al., 2016). The nonprofit organizations may also derive value from a service project that extends beyond that of a community person(s) volunteering for generic tasks. The 
organization may benefit from advanced skills of students. Furthermore, since students are graded on the service learning projects, motivation and commitment to quality may be high.

When service learning projects are initiated, Chuang and Chen (2013) emphasize the importance of careful planning and design. Accordingly, this paper will examine the design of service learning deliverables as well as undergraduate student participation within an interdisciplinary business Corporate Social Responsibility (CSR) class that completed marketing activities for community nonprofit organizations. Such examination may be beneficial if other faculty care to implement a similar design for their business classes.

\section{LITERATURE REVIEW}

In this section, literature is reviewed that supports the increased creativity and team benefits when participating in interdisciplinary projects. Last, the nature of CSR and sustainability is examined to show that interdisciplinary projects are best suited for CSR.

\section{Creativity}

The use of interdisciplinary learning is meritorious in that it expands students' understanding by encouraging students to form novel connections between disparate subjects, which often results in expanded insight and creativity (Liftig, 2015). This use of creativity can be applied to refining existing ideas as well as to generating new ideas. Furthermore, the studying of disparate subjects can strengthen analogical imagination leading to creativity problem solving. For example, Leonardo DaVinci exemplified the use of analogical imagination as he studied the flow of the river, the flow of blood to the heart, and the flow of molten wax; DaVinci was then able to form the "principle of the conversation of volume" (Lion \& Gunderman, 2019, para. 13). Additionally, Steve Jobs contends that creativity is a result from connecting the dots of diverse experiences followed by the act of synthesis. Unfortunately, Jobs noted that too many people do not have enough diverse experiences. Finally, the mathematician Maryam Mirzakhani explains, "I like crossing the imaginary boundaries people set up between different fields-it's very refreshing... It's about being optimistic and trying to connect things" (Root-Bernstein, 2015, para. 26).

\section{Teams}

Coffey and Wang (2006) advocate the utilization of teams to resolve real-world business issues. When students work on a project team to address an interdisciplinary problem or opportunity, additional benefits are derived beyond a team's creativity. Members will make connections from the diverse subjects to determine what frameworks to use for the final project. Members will also synthesize the diverse subjects in a way to create a usable end result for the interdisciplinary recipient. Even though the project is being completed as a team, individual reflection of the interdisciplinary project is an important aspect to include (Woods, 2007).

\section{CSR and Sustainability}

Before addressing the value of using interdisciplinary projects for CSR, some definitions of sustainability and CSR will be shared. The meaning of CSR is expansive in the sense that there is no official meaning (Bansal, 2005; Carroll, 1999; Runhaar \& Lafferty, 2009). Bierema and D'Abundo regard CSR as an organization's social conscience (2004). Additionally, CSR takes into account an organization's ethical actions and decisions to improve the lives of their stakeholders (Carroll, 1999; Garriga \& Mele, 2004; Hopkins 2003; Maignan \& Ralston, 2002). An organization's CSR initiatives typically involve participating in some type of actions that expand what the organization is legally required to do in the workplace (McWilliams \& Siegel, 2001). In addition to social, ethical, environmental, and stakeholder dimensions, a volunteer dimension can also comprise CSR (Christensen, Peirce, Hartman, Hoffman, \& Carrier, 2007; Dahlsrud, 2008).

Sustainability is regarded as an approach to solve today's environmental, social, and economic problems such that future generations do not incur the negative impact of such problems (Robinson, 
2012). Szekely and Knirsch (2005) expand upon Robinson's definition with details focused on specific areas to sustain:

economic growth, shareholder value, prestige, corporate reputation, customer relationships, and the quality of products and services as well as adopting and pursuing ethical business practices, creating sustainable jobs, building value for all the stakeholders and attending the needs of the underserved. (p. 628)

Numerous theorists contend that the teaching of sustainability ought to be conducted in an interdisciplinary manner. Since sustainability is interdisciplinary, then the learning activities for students also should cross disciplinary boundaries (Vincent et al., 2012, 2013). Additionally, Metzger, Blockstein, and Callahan (2017) rationalize that due to the complexity of sustainability issues, best practices from multiple disciplines are necessary to effectively teach the subject of sustainability.

Perez-Batres and Pisani (2010) assert that sustainability comprises CSR. Also, other theorists use CSR and sustainability interchangeable (Jensen, 2007; Jose \& Lee, 2007; Moon, 2007; Porter \& Kramer, 2006). For purposes of this paper, the terms of CSR and sustainability will be exchangeable. Hence, the rationale for incorporating an interdisciplinary project for teaching sustainability is applicable for teaching CSR.

\section{OVERVIEW OF THE SERVICE PROJECT}

An interdisciplinary service project was created for three sections of an undergraduate CSR course at a small private university. In addition to the benefits and goals listed within the Literature Review, the instructor had several other goals. First, the instructor wanted a service project that differed from other current noncourse service projects like volunteering time at a nursing home, humane society, or Habitat for Humanity. Second, the instructor wanted students to engage in a service project that would enhance skills that could be included on students' resumes and would be beneficial to employers. Last, the instructor wanted students to engage in a service project that extended such that even though the semester ended, some students might continue volunteering their skills in that service.

The instructor decided upon a CSR Marketing service team project. Since the course was being taught in hybrid mode, the instructor allocated 22 hours of out-of-class time for each student for the CSR Marketing service project. Students were responsible for logging their time and periodically submitted a time log for review.

Three main deliverables comprised the CSR Marketing service project.

\section{Deliverable 1: CSR Marketing Analysis Report}

The instructor provided students with a CSR Marketing Analysis Report so students had a roadmap to follow to properly inventory the organization's marketing initiatives and to analyze what new/enhanced marketing initiatives were needed (see Appendix A).

Students would begin by reviewing the organization's current marketing initiatives so that changes or additional marketing initiatives could be recommended. Students would then have to implement 1 or more initiative. The selected marketing initiatives could include the following activities: writing Press Releases, creating and maintaining a WordPress website, analyzing email campaign vendors, creating an email blast campaign (if the organization pays the cost), creating a Facebook page, making posts to the Facebook page, creating a library of free images, and more. Students would also have to train the organization and would have to create training materials or a training video to leave behind.

\section{Deliverable 2: CSR Marketing Action Plan}

The instructor wanted to encourage students to avoid deciding on a marketing initiative(s) at the last minute, so she included a second deliverable which was an action plan that was completed after students completed Deliverable 1 (see Appendix B). When determining marketing initiatives for the action plan, students were reminded that they needed to accumulate at least 22 hours. Also, students were told that they 
would work individually or with their team members on the projects they selected. Last, the instructor encouraged students to participate in marketing initiatives that would help them to develop additional skills to make them more marketable for employers and for their job search.

\section{Deliverable 3: Final Presentation and Reflection Paper}

At the end of the semester, student teams had to make a presentation on their project discussing their nonprofit organization and contributions. Additionally, each member had to share personal reflection regarding what students admired about the organization, the student's contribution, the impact on the student's life, and the impact of the contribution to the organization (see Appendix C). Last, students had to complete peer reviews of each other.

\section{FORMATION OF INTERDISCIPLINARY TEAMS}

To better assist each team with a mix of skills needed for the CSR Marketing service project, the instructor prepared a Skills Inventory Sheet (see Appendix D). Students were asked to list their names, type of experience and/or classes associated with writing press releases, using Facebook, creating websites, finding royalty-free pictures, creating email blasts, creating videos, using Twitter, or using Pinterest. Additionally, students shared if they had taken marketing classes and if they were pursuing a marketing major or minor. The instructor then referenced this sheet to ensure students with backgrounds in multiple categories were included in each team.

\section{ORGANIZATIONS}

Prior to the start of the semester, the instructor wanted to create a list of possible organizations for students to consider. In addition to her own awareness of organizations, she checked with several faculty members to get their input. She also contacted the local Director of the United Way for recommended organizations. Last, based upon reading news in the local newspaper, she added organizations or individuals who exemplified good deeds to her list. The instructor then sent an email to each organization to determine the level of interest for a student service project involving marketing (see Appendix E).

Each student team was given the opportunity to choose from the instructor-supplied list, or students could present for approval their own discovered nonprofit organization or an individual who was doing good deeds. The organizations and individuals selected for this service project from students in the three classes are in Figure 1. A description of the service requested by each organization/individual is also included.

The instructor subsequently sent an email to nine nonprofits letting them know that student teams would be in contact with them soon (see Appendix F). She asked the organizations to be responsive in students' requests to meet with them. Additionally, the instructor shared the CSR Marketing Analysis Report that students would be receiving so that the nonprofits would understand the meeting and prepare for the meeting. The organizations were very enthusiastic and appreciative to receive students' help for marketing initiatives whose impact would continue long after the semester ended. 


\section{FIGURE 1 \\ CATEGORIES OF ORGANIZATIONS AND INDIVIDUALS SELECTED FOR THE CSR MARKETING SERVICE PROJECT}

\begin{tabular}{|c|c|}
\hline Ministry & $\begin{array}{l}\text {-Would like a website using Godaddy template and a } \\
\text { Facebook page }\end{array}$ \\
\hline Animal Response & - Seeking student recommendations \\
\hline Domestic Violence & -Would like to set up an email campaign \\
\hline Sewing Crafts & -Would like a Facebook page \\
\hline Economic Opportunity & - Seeking student recommendations \\
\hline Religious Alliance & -Seeking student recommendations \\
\hline Youth Development & -Would like a brand compliant website \\
\hline Inclusivity & -Seeking student recommendations \\
\hline Children & -Would like to increase Facebook presence \\
\hline Disabilities & -Would like a website \\
\hline
\end{tabular}

\section{RESULTS}

Based upon the marketing efforts of students, common completed marketing projects will now be discussed.

Each student team had general discussions on numerous types of social media and marketing tools that could be beneficial to the nonprofit organizations. In some cases, students also provided light training as part of their discussions since some of the nonprofit contacts were not familiar with the jargon. The type of Social Media and marketing tools discussed includes Instagram, Google Plus, Foursquare, Tumblr, Pinterest, Hootsuite, Twitter, Websites, and Facebook.

Working on the marketing activity of websites was common for student teams. In some instances, students created a website from scratch, designed pages, and provided website tutorials for creation and maintenance. In other instances, students reviewed existing websites and recommended changes such as the inclusion of Social Media buttons, adding fresh content, and changing pictures.

Some student teams worked on Facebook for their nonprofits. As with websites, some teams created a Facebook account as none had existed before. Students also assisted nonprofits with Facebook daily posts. Additionally, one team also developed a Facebook training manual discussing topics like adding friends/photos, posting updates and as advertising/promoting using Facebook.

Some student teams focused on press releases. Students provided a Press Release template with stepby-step comments within the margins to ensure guidance when completing later. Students also researched and compiled a list of local media channel contacts to use for future press releases.

The need for email blasts was another common area worked on by student teams. This marketing initiative involved creating email last templates. For example, one student team set up email blast templates for each of these areas:

- Solicitation template (Encouraged donations from past donors, sent to new potential donors, streamlined to the Donate Now buttons, included information about what the donation is used for)

- News release template (Sent on Weekly/Bi-Weekly basis, provided information to members, donors, and sponsors, linked to website that provided a mechanism for donor support and additional information) 
- Event update template (Intended to encourage participation at major events as majority of funding is sought at these events)

- Thank you template (Showed appreciation for donor and sponsor funding, reminded donor of the organization's mission and programs, showed what their donation is helping within the organization)

Creating a Twitter page was also common among teams. Some members developed example content like pictures, events, and activities. Others developed a plan to use the Hashtag and a timeline of different posts. Some students were also involved with updating the Twitter page as well as preparing Twitter training material.

Several other marketing initiatives were less commonly performed by student teams. For example, one team was asked to develop a marketing program that could be used by marketing student interns. Therefore, the team developed a 7-page handbook that outlines an intern's duty throughout their time at the organization. In another example, a team found royalty free pictures to create an Image file. Another team provide training on how to use Instagram. Last, another team developed a survey using SurveyMonkey.

\section{DISCUSSION}

In reviewing the service time and the marketing projects completed, numerous benefits resulted for the nonprofit organizations and the students.

\section{Organizational Benefits}

In addition to the completed marketing initiatives, several organizations reported revitalized hope that their goals would be better met due to the students' projects. For example, one organizational contact shared that community volunteers' time was often utilized on generic tasks that did not require significant or specialized training. Also, the organizational contact and staff did not have those skills either. The organization knew it needed marketing. However, the organization could not afford that service and did not have volunteers or staff with such skills, so the organization lost its sense of hope. As a result of the students' effort, the organization reported revitalized hope that their goals would be better met due to the students' projects.

\section{Student Benefits}

Based upon individual reflection, numerous benefits were derived by students that are grouped into thematic categories.

\section{How the Service Experience Felt}

Some students described a positive experience that was derived from the act of performing marketing service using descriptors like fun, felt great, felt good, and enjoyed. Some students also reflected upon the aftermath feeling when the marketing service activities had been completed using descriptors like personally satisfying, rewarding, and gratifying. The latter type of reflection can be viewed as a type of reciprocity - students gave of themselves to serve the organization and then the organization gave back to the student a positive aftermath feeling.

\section{Learning}

In reflection, some students noted that learning had occurred as part of the service experience, stating that they learned a lot and that the service experience was intellectually stimulating. Furthermore, some student discovered that learning occurred in specific areas that were described within the areas of technology and email blast systems and templates. Students also felt they were more skilled in communicating in a professional manner, working with a team, overcoming obstacles, and doing certain aspects of business. Last, some students realized the opportunity to transfer the knowledge and experience gained from the marketing service project to their own projects. For example, one student noted the transfer 
from the marketing service project to his personal use in building a website, while another student planned to build a website for her father's company.

\section{Personal Effects Resulting From the Nonprofit Organization}

When reflecting upon the marketing service experience, a few thematic effects emerged for students. The first was an increase in clarity and empathy for the nonprofit organization. A student admitted to secretly questioning the rationale for the organizational contact's commitment of time and money towards nonprofit initiative and then eventually realized that a motivating factor is the satisfaction of bringing joy out of a hard time in someone else's life. Another student mentioned that he had always wanted to be a businessman who made as much money as possible but now understood another side of businesses that are trying to provide a very admirable service. Students' empathy also increases as they said they came to understand how difficult it is for some people or one individual to run an organization and the responsibilities one must take on. Additionally, students felt they had much more respect for those individuals who are working/running a non-profit organization and admired the help that the nonprofit organizations provided. A final effect is an expansion of students' breadth of understanding and empathy of other organizations and causes. Such students referenced an insightful awareness about broad social issues as well as an appreciation of the things that they have in life and how important life itself is.

\section{Increased and Expanded Volunteering}

Students were inspired to continue with additional volunteer activities at their same class nonprofit organizations as well as at new nonprofit organizations as they stated that it's the right thing to do. Furthermore, students were inspired to expand the volunteer effort by involving other individuals like classmates. Additionally, a student discussed the experience with siblings, relatives, and some of friends who all expressed an immediate confirmation to get involved. Some of the expanded involvement occurred during the class term such that the student initiating the expanded volunteer involvement commented that their time together was great and volunteering gave them the opportunity to have a shared experience for a meaningful cause.

\section{Identified Significance to the Nonprofit Organization}

As the project was completed, students were able to reflect upon its significance, noting that the organization's employees desperately needed someone to help them and the team's contributions made a lasting impact. Such significance was reinforced by student's interpretations of the organization's contact as they described her as extremely grateful for the effort and thanked the group again and again. Last, students also affirmed that the look of astonishment found on the organization's worker's face was priceless.

\section{CONCLUSION}

The use of service learning projects are beneficial both to students and the selected organizations as students engage in action learning and apply theoretical knowledge into their community. Enhancing these projects to be interdisciplinary is especially beneficial because the area of CSR itself is interdisciplinary -the complexity of CSR requires a multi-disciplinary approach in real life. Accordingly, the pairing of CSR and marketing was utilized to create a CSR Marketing Service team project. The design of this project has been delineated such that other instructors may have a model to create a similar Marketing service learning project to be combined with CSR or a different topic area. Reflection from students and feedback from the nonprofit organizations show that a positive impact occurred during the action learning project itself and after the service project ended. Last, Pound and Moore highlight workplaces' interest in encouraging their employees' service to the community and think that students who engage in such experiences in their classrooms may be motivated to continue with service projects with their employers (as cited in Coffey \& Wang, 2006; Pajo \& Lee, 2011). 


\section{REFERENCES}

Bailey, P., Carpenter, D., \& Harrington, P. (1999). Integrating community service into education: A guide to service-learning. New York, NY: Springer.

Bansal, P. (2005). Evolving sustainably: A longitudinal study of corporate sustainable development. Strategic Management Journal, 26(3), 197-218.

Behrman, J.N., \& Levin, R.I. (1984). Are business schools doing their job? Harvard Business Review, $62(1), 140-147$.

Bennis, W., \& O'Toole, J. (2005). How business schools lost their way. Harvard Business Review, 83(5), 96-104.

Bierema, L., \& D'Abundo, M. (2004). HRD with a conscience: Practicing socially responsible HRD. International Journal of Lifelong Education, 23, 443-458.

Campbell, C.G., \& Oswald, B.R. (2018). Promoting critical thinking through service learning: A homevisiting case study. Teaching of Psychology, 45(2), 193-199. doi:10.1177/0098628318762933

Carroll, A.B. (1999). Corporate social responsibility. Evolution of a definitional construct. Business \& Society, 38(3), 268-295.

Celio, C.I., Durlak, J., \& Dymnicki, A. (2011). A meta-analysis of the impact of service-learning on students. Journal of Experiential Education, 34(2), 164-181.

https://doi.org/10.1177/105382591103400205

Christensen, L.J., Peirce, E., Hartman, L.P., Hoffman, W.M., \& Carrier, J. (2007). Ethics, CSR, and sustainability education in the financial times top 50 global business schools: Baseline data and future research directions. Journal of Business Ethics, 73(4), 347-368. doi:10.1007/s10551-0069211-5

Chuang, K., \& Chen, K. (2013). Designing service learning project in systems analysis and design course. Academy of Educational Leadership Journal, 17(2), 47.

Coffey, B.S., \& Wang, J. (2006). Service learning in a Master of Business Administration (MBA) integrative project course: An experience in China. Journal of Education for Business, 82(2), 119-124. Retrieved from http://ezaccess.libraries.psu.edu/login?url=https://search-proquestcom.ezaccess.libraries.psu.edu/docview/202819887? accountid $=13158$

Cone. (n.d.). 2017 Cone communications CSR study. Retrieved from https://www.conecomm.com/research-blog/2017-csr-study

Cummings, T. (2007). 2006 Presidential address: Quest for an engaged academy. The Academy of Management Review, 32(2), 355-360. Retrieved from www.jstor.org/stable/20159305

Dahlsrud, A. (2008). How corporate social responsibility is defined: An analysis of 37 definitions. Corporate Social Responsibility and Environmental Management, 15(1), 1-13. doi:10.1002/csr.132

Edelson, S.A., Senk, C.C., \& Stock, K.L. (2018). Using an integrated business experience to take the place of "introduction to management" in an integrated curriculum. Journal of Education for Business, 93(7), 332-340. https://doiorg.ezaccess.libraries.psu.edu/10.1080/08832323.2018.1490684

Garriga, E., \& Melé, D. (2004). Corporate social responsibility theories: Mapping the territory. Journal of Business Ethics, 53(1/2), 51-71. doi:10.1023/B:BUSI.0000039399.90587.34

Grey, C. (1996). Introduction. Management Learning, 27(1), 7-20. https://doi.org/10.1177/1350507696271002

Guo, F., Yao, M., Wang, C., Yan, W., \& Zong, X. (2016). The effects of service learning on student problem solving: The mediating role of classroom engagement. Teaching of Psychology, 43(1), 16-21. doi: $10.1177 / 0098628315620064$

Hopkins, M. (2003). The planetary bargain: Corporate social responsibility matters. Sterling, VA: Earthscan.

Jensen, H.B. (2007). From economic to sustainable development: Unfolding the concept of law. Systems Research and Behavioral Science, 24, 505-513. 
Jose, A., \& Lee, S.M. (2007). Environmental reporting of global corporations: A content analysis based on website disclosures. Journal of Business Ethics, 72, 307- 321.

Liftig, I. (2015). Interdisciplinary teaching. Science Scope, 39(2), 1-1.

Lillo, S.R. (2019). In pursuit of community engagement: Unpacking the knowledge and skills associated with service-learning efforts. Journal of Research in International Education, 18(1), 3-22. doi:10.1177/1475240919829997

Lion, A., \& Gunderman, R.B. (2019). How intrapersonal diversity enhances creativity: Leonardo da Vinci. Academic Radiology, 26(7), 999-1000. doi:10.1016/j.acra.2019.02.005

Maignan, I., \& Ralston, D.A. (2002). Corporate social responsibility in Europe and the U.S.: Insights from businesses' self-presentations. Journal of International Business Studies, 33(3), 497-514. doi:10.1057/palgrave.jibs. 8491028

McCord, M., Houseworth, M., \& Michaelsen, L.K. (2015). The integrative business experience: real choices and real consequences create real thinking. Decision Sciences Journal of Innovative Education, 13(3), 411-429. https://doi-org.ezaccess.libraries.psu.edu/10.1111/dsji. 12070

McWilliams, A., \& Siegel, D. (2001). Corporate social responsibility: A theory of the firm perspective. Academy of Management Review, 26, 117-127.

Metzger, E.P., Blockstein, D.E., \& Callahan, C.N. (2017). Interdisciplinary teaching and sustainability: An introduction. Journal of Geoscience Education, 65(2), 81-85. doi:10.5408/1089.9995-65.2.81

Moon, J. (2007). The contribution of corporate social responsibility to sustainable development. Sustainable Development, 15, 296-306.

Navarro, P. (2008). The MBA core curricula of top-ranked U.S. business schools: A study in failure? Academy of Management Learning \& Education, 7(1), 108-123. Retrieved from www.jstor.org/stable/40214503

Nokes, K.M., Nickitas, D.M., Keida, R., \& Neville, S. (2005). Does service-learning increase cultural competency, critical thinking, and civic engagement? Journal of Nursing Education, 44(2), $65-$ 70.

Pajo, K., \& Lee, L. (2011). Corporate-sponsored volunteering: A work design perspective. Journal of Business Ethics, 99(3), 467-482. doi:http://dx.doi.org. ezaccess.libraries.psu.edu/10.1007/s10551010-0665-0

Perez-Batres, L.A., \& Pisani, M.J. (2010). CSR, sustainability and the meaning of global reporting for Latin American Corporations. Journal of Business Ethics, 91(S2), 193-209. doi:10.1007/s10551010-0614-y

Porter, M.E., \& Kramer, M.R. (2006). Strategy and society: The link between competitive advantage and corporate social responsibility. Harvard Business Review, 84(12), 78.

Reynolds, M., \& Vince, R. (2004). Critical management education and action-based learning: Synergies and contradictions. Academy of Management Learning \& Education, 3(4), 442-456. Retrieved from www.jstor.org/stable/40214315

Robinson, Z. (2012). Sustainability. London; Abingdon: Marshall Cavendish.

Root-Bernstein, R. (2015). Arts and crafts as adjuncts to STEM education to foster creativity in gifted and talented students. Asia Pacific Education Review, 16(2), 203-212. doi:10.1007/s12564-015-93620

Runhaar, H., \& Lafferty, H. (2009). Governing corporate social responsibility: An assessment of the contribution of the UN global compact to CSR strategies in the telecommunications industry. Journal of Business Ethics, 84(4), 479-495. doi:10.1007/s10551-008-9720-5

Sedlak, C.A., Doheny, M.O., Panthofer, N., \& Anaya, E. (2003). Critical thinking in students' servicelearning experiences. College Teaching, 51(3), 99-104. doi:10.1080/87567550309596420

Székely, F., \& Knirsch, M. (2005). Responsible leadership and corporate social responsibility: Metrics for sustainable performance. European Management Journal, 23(6), 628-647.

Thomas, M.H., \& Smith, R.S. (2017). Building community engagement: Incorporation of service learning in a nursing curriculum. Nurse Education Today, 52, 63-65. doi:10.1016/j.nedt.2017.01.013 
Vincent, S., Bunn, S., \& Sloane, L. (2013). Interdisciplinary environmental and sustainability education on the nation's campuses 2012: Curriculum design. Washington, DC: National Council for Science and the Environment.

Vincent, S., Bunn, S., \& Stevens, S. (2012). Interdisciplinary environmental and sustainability education: Results from the 2012 census of US four-year colleges and universities. Washington, DC:

National Council for Science and Education.

Woods, C. (2007). Researching and developing interdisciplinary teaching: Towards a conceptual framework for classroom communication. Higher Education, 54(6), 853-866. doi:10.1007/s10734-006-9027-3

\section{APPENDIX A}

\section{CSR Marketing Analysis Report}

Prepare a report for the nonprofit organization and professor to contain the info listed below. Note: The time log by person is for the professor only and will be submitted with this CSR Marketing analysis report and at various points throughout the course.

\section{Section 1: Organization/individual background info. Use the labels below.}

1. Date of initial meeting (face-to-face or virtual)

2. Name of Nonprofit Organization/Individual

3. Website

4. Contact's info - name, title, email, phone

5. Description of the organization/individual's initiatives

\section{Section 2: Summary and Analysis:}

Please label these sections and add your content within the sections.

6. Website.

If there is an existing website, list and describe what is contained on each page in terms of a summary of the content, layout, color, etc. For each page, list the strengths and improvable areas (if any). For any improvable areas, be sure to include an example of the improvement by showing a screen print from another website or an image that would be helpful in understanding your recommendation, if applicable ---i.e. a screen print of a site showing thumbnails to click on for Facebook, Twitter, and Pinterest - i.e.

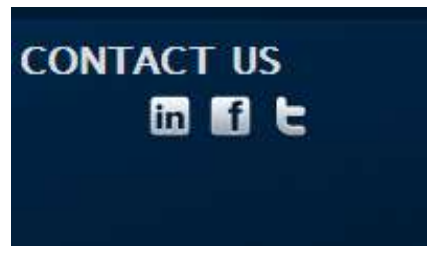

Last, list several urls for similar organizations' websites that your organization can visit to see examples of websites that in a similar industry.

If there is not an existing website, then recommend the number and types of website pages for the organization to consider. Create a single analysis page for each website page that you recommend. Each analysis page should be given a title (i.e. Home page, About Us page, and so on). On each analysis page, list questions that the organization would need to answer to generate content for that website page. Last, on each analysis page, also share if you think any particular types of images might be applicable. Your questions should successfully guide the organization to generate appropriate content 
such that someone can then create a custom website or a template website for the organization in the future.

Last, list several urls for similar organizations' websites that your organization can visit to see examples.

\section{Facebook}

If there is a Facebook page for the organization, summarize what has been done to date. Analyze the strengths. Analyze any improvements.

If there is not a Facebook page for the organization, provide your recommendations in terms of types of content that can be posted and your recommendations for upcoming occasions to post content.

\section{Press Releases}

What has been done in terms of press releases - content? Frequency? Analyze the strengths. Analyze any improvements.

\section{Library of images}

Has the organization established a library of free images? Analyze the strengths. Analyze any improvements. Research and prepare a list of sites offering royalty free images. Research and prepare a list of sites offering low cost images.

If the organization has not established a library of free images, prepare a list of recommended types of generic images and specific images that would be beneficial for the organization to find. Research and prepare a list of sites offering royalty free images. Research and prepare a list of sites offering low cost images.

\section{Email blasts.}

Does the organization participate in email blasts? If so, how - directly as an email message or through a vendor such as Mail Chimp, Constant Contact, My Emma, other? Does the organization capture and analyze any analytics -i.e. who has opted out, who has clicked on links, who has opened, who has forwarded, and so on.

If so, analyze the strengths. Analyze the improvements. Consider factors such as the type of email, the style of the email, and the message. Also, consider the size and quality of the emailing list.

If not, list and describe types of email initiatives that would be beneficial to the organization - if any. Discuss ways in which the organization might grow its email list.

\section{Other marketing initiatives.}

Describe any other marketing initiatives --- electronic or manual -i.e. bulk mailings, contests, fund raisers, interviews, radio, and so on. Analyze the strengths. Analyze any improvements. 


\author{
Summary Layout of CSR Marketing Analysis Report \\ Cover Page: \\ Title: CSR analysis for organization's name \\ Team members' names \\ Course name and section \\ Professor \\ Date \\ Section 1: Organization/individual background info. \\ 1. Date of initial meeting \\ 2. Name of Nonprofit Organization/Individual \\ 3. Website \\ 4. Contact's info \\ 5. Description of the organization/individual's initiatives \\ Section 2: Summary and Analysis: \\ 6. Website \\ 7. Facebook \\ 8. Press Releases \\ 9. Library of Images \\ 10. Email Blasts \\ 11. Other marketing initiatives
}

\title{
APPENDIX B CSR MARKETING ACTION PLAN
}

For this deliverable, please list the projects that you have selected to complete for the nonprofit organization or individual. Please note that you will need to accumulate at least 22 hours so you may need to select one of more projects in this semester. Accordingly, this action plan may later be modified if you need more hours. You can work individually or with multiple members on the projects you select. It is recommended that you also develop additional skills to make you more marketable for employers and your job search. As an example, if you have never developed a website from a template and another team member is doing so, you may want to watch and create the training material.

Here are some examples of project you may decide to work on for your nonprofit organization or individual. This list is not exhaustive so feel free to add more.

\section{Examples of projects:}

- Assist organization in further defining content for website pages

- Work with organization to define categories of pictures. Search for royalty free pictures or take pictures that do not need permission agreed to and that do not violate privacy --- i.e. season pictures of nature, pictures, of awards, pictures of projects

- Write current and future (staged) press releases

- Research numerous sources, and write a formal paper listing tips for content to be posted on Facebook. Be sure to include a cover page and references.

- Research numerous sources, and write a formal paper listing ideas for press releases. Be sure to include a cover page and references.

- Research numerous sources, and write a formal paper listing tips for encouraging others to share their email list for email blasts. Be sure to include a cover page and references.

- Research numerous sources, and write a formal paper listing vendors who offer email blast services. Then determine categories you will compare such as price, terms of contract, analytics, etc. Also, include your comparison in a schematic. Be sure to include a cover page and references. 
- Research numerous sources, and write a formal paper listing vendors who offer free or inexpensive virtual meetings services that can be used by members for planning for meetings with donors. Then determine categories you will compare such as price, strengths, weaknesses, etc. Also, include your comparison in a schematic. Be sure to include a cover page and references.

- Create a website from a template.

- If your team created a website, then also create training material: 1). How to create a website from the template, 2). How to modify the template website. The training material needs to be in MS Word or as a presentation (i.e. PPT) AND in video format to allow for different learning styles. Last, conduct training with your organization in person.

- Create a Facebook page and posts

- If your team created a Facebook page and posts, then also prepare training material: 1). How to create a Facebook page, 2). How to make posts. The training material needs to be in MS Word or as a presentation (i.e. PPT) AND in video format to allow for different learning styles. Last, conduct training with your organization in person.

- Create an email blast newsletter/announcement from the template

- If your team created an email blast newsletter/announcement, then also prepare training material: 1). How to create, 2). How to make changes. The training material needs to be in MS Word or as a presentation (i.e. PPT) AND in video format to allow for different learning styles. Last, conduct training with your organization in person.

- Provide in person training and handouts to your organization in tools of technology that may be helpful for that organization's growth such as:

- Taking digital pictures

- Getting digital pictures from phone or camera to computer

○ Renaming pictures

○ Resizing pictures

- Smart Phone capabilities: making a recording, taking pics, making a video, scheduling events, adding members' names to contacts

- Using the computer to make a recording or a video

- Using a snipping tool

- Setting up a Twitter account and recommending use

\section{APPENDIX C FINAL PRESENTATION AND REFLECTION PAPER}

1. Team presentation:

a. Approximately 15 minutes

b. Share background info on the nonprofit organization or individual. Best to incorporate some type of visuals --- i.e. existing website, existing Facebook page, pictures of initiatives from that organization, etc. ---if possible

c. Showcase some of your team's hands-on initiatives

2. Individual Papers -- share your reflection on:

a. Background info on this nonprofit organization or individual

b. What you admire about the organization or individual and explain why

c. What you contributed

d. How your involvement has impacted your life

e. How your contribution has assisted this nonprofit organization or individual

f. Page length: approximately 2-3 pages double spaced 


\title{
APPENDIX D \\ SKILLS INVENTORY SHEET
}

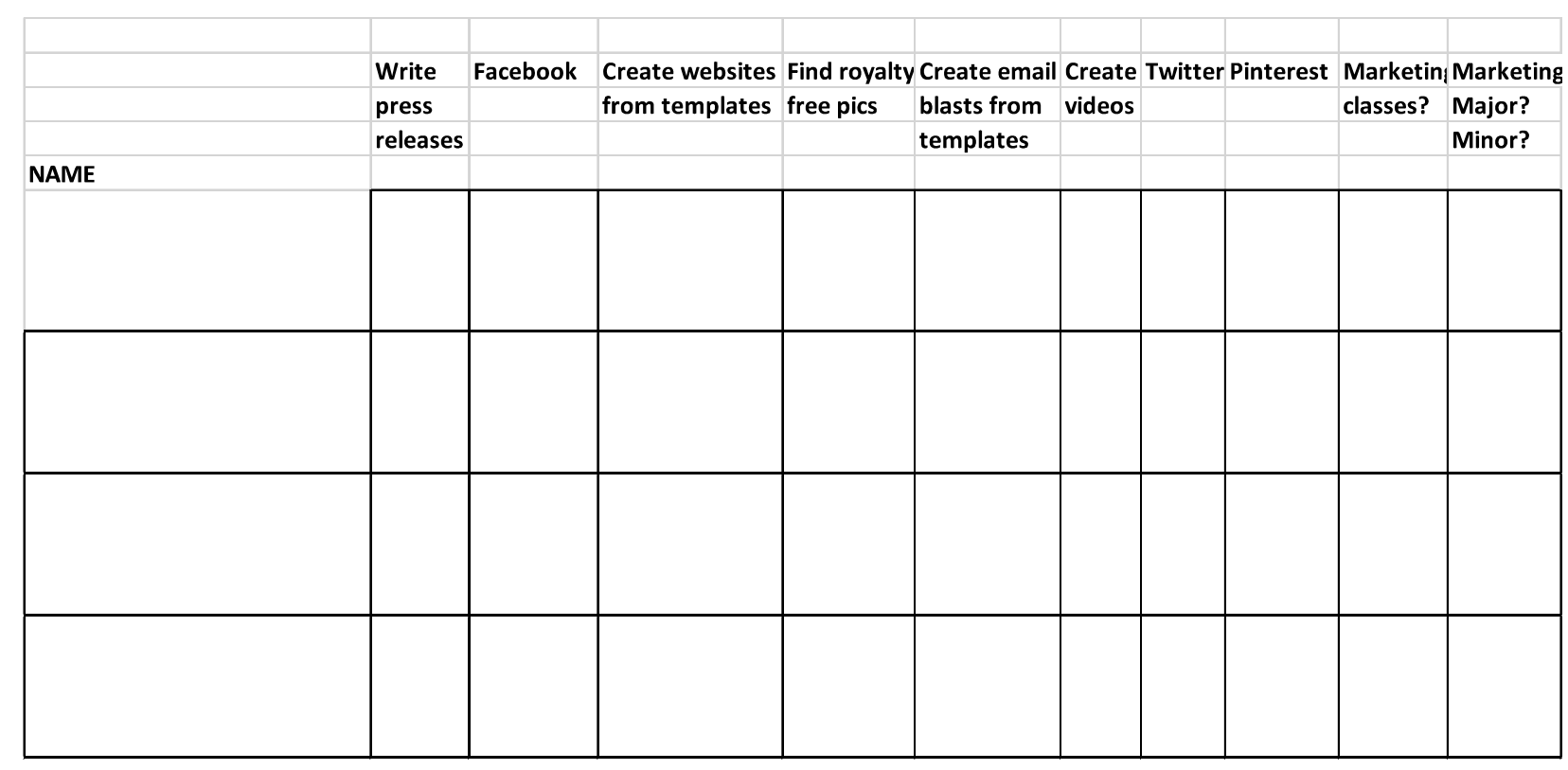

\section{APPENDIX E INQUIRY LETTER SENT TO NONPROFIT ORGANIZATIONS}

\section{Dear XXX,}

This fall, I am teaching a class on The Social Responsibility of Business. I have created an assignment in which students must engage in a service project. Students will assist one or more nonprofit organizations or individuals who are doing good deeds (i.e. coaches, etc.). Students must review the organization's or individual's current marketing initiatives and recommend changes or additional marketing initiatives. Last, students will have to implement 1 or more marketing initiatives. Some of the marketing initiatives may span any (but not all) of the following: Press Releases, setting up and maintaining a blog, setting up and maintaining a WordPress website, providing a comparison of email campaign vendors, setting up an email blast campaign (if organization purchases one), setting up a Facebook page, making posts to the Facebook page, etc. Students will also have to train the organization or individual and will have to create training materials and a training video to leave behind.

Would you have an interest in a team of students analyzing your current marketing initiatives, making marketing recommendations, and implementing some marketing initiatives? If so, I can add your organization to the list I am creating for students to consider and make their selection.

\author{
Warmest regards, \\ Instructor's Name \\ Instructor's Contact Information
}




\section{APPENDIX F \\ LETTER SENT TO NONPROFIT ORGANIZATIONS TO INFORM THEM OF STUDENTS' CONTACT}

Hi all,

Great news! A student team will be in touch with you soon from our "Social Responsibility of Business" class. To recap, the 3 phases that students will focus on for you include:

1. Analysis of your current marketing/social media initiatives

2. Determining 1 or more projects and implementing 1 or more projects

3. Training - handouts (MS Word or ppts) + video

Within a 2-week timeframe, students need to communicate with their nonprofit organization or individual such that they can gather information, analyze current initiatives, and prepare an analysis report to be submitted to you and to me. For your convenience, I am attaching the template of the analysis report that they must prepare for you and for me. Some of the information they can gather online without your assistance. For other information, students will need to communicate with you by phone, email, or in person. If you could be responsive to their communication, that would help them to complete their work on time and avoid late point deductions. Also, you may wish to review the template such that you can think about your responses or gather information that might be helpful for students to see.

After this analysis report has been completed, students will move on to Phase 2 to hone in on one or more marketing/social media initiatives to complete for you at a later date. Then, they will prepare training material such that you or someone else can continue on with their initiatives. 